\title{
Nuclear Receptor ROR-Gamma T
}

National Cancer Institute

\section{Source}

National Cancer Institute. Nuclear Receptor ROR-Gamma T. NCI Thesaurus. Code C106314.

Nuclear receptor ROR-gamma T (497 aa, $56 \mathrm{kDa}$ ) is encoded by the human RORC gene.

This protein is involved in both ligand-dependent transcriptional regulation and the differentiation of helper T-cells. 